\title{
Restoring West Africa to its Past in Chinua Achebe's Things Fall Apart and Mary Kingsley's Travels in West Africa
}

\author{
Bechir Chaabane \\ English Language Department \\ Faculty of Arts and Humanities of Sousse \\ University of Sousse, Tunisia
}

\begin{abstract}
:
The article is inspired by Achebe's belief that human stories should be told from distinct perspectives to grasp all it intents. The story of Umuofia, the fictitious Igbo village, in Achebe's Things Fall Apart (1958) can be read intertextually in light of the non-fictional text of Mary Kingsley, Travels in West Africa (1897) to underline the thrust of authenticity and fidelity of Achebe that makes his fiction true to life. This juxtaposition is further staged to question the stereotypical representation of Africa and Africans through the fictional texts of $19^{\text {th }} \mathrm{c}$ British writers such as Joseph Conrad, Rider Haggard among many others. Though it is not a purely historical text, Things Fall Apart is spearheaded against the reductive approach applied by $19^{\text {th }} \mathrm{c}$ British writers to deny Africa history and culture wholesale, presenting it on a dire need for the enlightenment and mission civilisatrice of the Westerners. Hence, the ostensible aim to enlighten the African heathens living in utter darkness, to free the African minds from the enslavement of superstition, to liberate African women from the sexual laxity endorsed by the barbaric morals of heathenism is counterpointed in Achebe's Things Fall Apart. Chiefly, Achebe states that the cultural practices of the African people in their particular African environment down through ages have catered them with particular insights into life that are the bedrock of values and outlooks shaping contemporary African life. The same insights are confirmed in Kingsley's text Travels in West Africa.

Keywords: Africa, culture, enlightenment, history, identity, Igbo, nativism, resistance, stereotype

Cite as: Chaabane, B. (2018). Restoring West Africa to its Past in Chinua Achebe's Things Fall Apart and Mary Kingsley's Travels in West Africa. Arab World English Journal for Translation \& Literary Studies, 2 (1). DOI: http://dx.doi.org/10.24093/awejtls/vol2no2.2
\end{abstract}

